\title{
An Exploration on the Application of Scaffolding Instruction into ESP Course
}

\author{
Wei Liu \\ School of Foreign Languages, Jilin Agricultural University, ChangChun 130118, China \\ 29897259@qq.com
}

\begin{abstract}
English for special purpose (ESP) is a practical English course which is related to the subject after finishing Basic English courses in the University. At present, there have been no specific national requirements for ESP and there is no consensus on what teaching mode should be used for ESP, either. The scaffolding instruction based on the theory of constructivism and Vygotsky's theory of the zone of proximal development (ZPD) takes the students as the center and gradually helps the students to construct their own framework of knowledge. The application of scaffolding instruction into ESP Course is undoubtedly constructive.
\end{abstract}

Keywords: Scaffolding Instruction; Constructivism; Zone of Proximal Development (ZPD) ; English for Special Purpose (ESP).

\section{Introduction}

English for special purpose (ESP) as a branch of English linguistics is mainly relative to English for general purpose (EGP). This subject first rose in the English speaking countries in the 60s in twentieth Century, and then the research on its theoretical system and related courses gradually enriched, and in 70s and 80s of the last century, it began to affect our country. In our country, the initial ESP courses included courses of English for science and technology and for international trade. However, "compared to the systematic research on ESP abroad, domestic research on it is quite limited. Many articles are still concerned with the introduction of research results abroad. There are just a few combining their experience with the exploration on teaching mode of ESP in the university (Shu Dingfang, 2004:103). The scaffolding instruction based on the theory of constructivism and Vygotsky's theory of the zone of proximal development (ZPD) is a teaching mode which takes the students as the center and gradually helps the students to construct their own framework of knowledge. The application of such teaching mode in ESP Course is undoubtedly constructive.

\section{The Definition and Characteristics of ESP}

ESP and EGP is that ESP is more practical and functional. ESP is a course which is designed to develop college students' English competency in a specific occupation or subject to meet needs in society, such as Computer English, Agricultural English of Science and Technology, Medical English, Financial English, News English, etc.. In the 1960s, Halliday, Mclntosh and Strevens put forward the definition of ESP in their book "The Linguistic Sciences and Language Teaching". They defined ESP as "English for civil servants; for policemen; for officials of the law; for dispensers and nurses; for specialists in agriculture; for engineers and fitters" (Halliday et al, 1964:51). Strevens (1988:1-13) put forward four distinctive features of ESP teaching: "Needs to meet specific learners; Content relates specific profession and occupation; Centered on the language appropriate to those activities in syntax, lexis, discourse, semantics, etc. and analysis of this discourse; In contrast with EGP". Since then, many scholars have complemented or attempted to amend Strevens' definition of ESP. But whatever the definition is, the real value of ESP is its practice.

\section{Scaffolding Instruction}

Scaffolding instruction was first proposed in 1970s by American education expert and psychologist Bruner. Here scaffolding is used to describe the conceptual framework to help students 
solve problems construct their knowledge system. The research on the scaffolding instruction is late in our country, but it develops rapidly and increasingly deeply.

\subsection{The Definition of Scaffolding Instruction}

In terms of scaffolding instruction, scholars at home and abroad have defined it from different perspectives. So far, the one accepted widely comes from the "distance education and training program" (DGXIII) in European Community: "scaffolding instruction should provide a conceptual framework for learners to construct their systems to understand knowledge. The concept of the framework is essential for learners to develop their ability to have a further understanding. Therefore, the complex task should be broken down into easier ones by instructors so as to deepen the learners' understanding". From this definition, it can be seen that in scaffolding instruction, learning is not finished by teaching students the ready-made knowledge or skills, but exploring knowledge themselves assisted by teachers or more capable others. In this process, learners can build their own knowledge and skills framework in order to achieve a higher goal with the help of teachers and more capable others based on their present ability.

\subsection{Theoretical Basis}

(1) Constructivism: Constructivism holds that learning can not be satisfied with the dogmatic master for knowledge, and students' minds should not be confined by the standard of teachers and authorities, but encouraged to study and analyze the rationality of knowledge, forming their own understanding and judgment. Students should process their knowledge by analyzing, criticizing and integrating it and use it flexibly; teachers own their new roles --- the tutor, senior partner. Constructivism also stresses that teachers should give guidance and assistance in the process of autonomous learning, which provides a basic theory for scaffolding instruction.

(2) The Theory of ZDP; Vygotsky believes that in students' intelligence activities, there is a gap between problems and their ability to solve problems, and through teaching, students can eliminate this gap with the teacher's assist. Such gap is the most ZDP. He further points out that the ZDP refers to the area between students' ability to solve problems at present and the potential develop level that the students are able to solve the problem with the help of adults or more experienced peers. Thus, it can be concluded that the ZDP can be created by teaching and the state between the first and second level of development is determined by teaching. Therefore, teaching should never be a negative way to adapt to students' intellectual development, but should go in front and try to improve students' intelligence from one level to another.

\section{The Application of Scaffolding Instruction in ESP Course}

Scaffolding instruction is a process under constructivism, in which learners gradually establish their own learning systems and knowledge frames with the guidance and help (scaffolding) of teachers and more capable others based on their present ability, and then removed their help (scaffolding). In ESP course, scaffolding instruction should be applied as follows.

\subsection{Building Scaffolding}

Teachers should determine the students' ZDP based on their actual needs, which requires teachers to fully understand the actual level of students. Because the scaffolding (the guideline and help) teacher provided is based on the level of the students, and it is not beneficial for students no matter it is too high or too low --- being too high means too difficult for student accept; being too low is meaningless to learn. Types of scaffolding can be examples, problems, suggestions, guides, charts, media (with the aid of graphics, case, image data), task (for the purpose of the task), material (for students to operate, practice and physical), and the like.

Generally, ESP course is set after students finish EGP course, which means students have mastered some English and professional knowledge. Teachers should combine the teaching content and the characteristics of related subjects in order to establish the students' learning sequence, objectives and requirements, and select appropriate scaffolding when preparing for the classes. Now modern communication and multimedia technologies provide convenience for ESP. 


\subsection{Entering Learning Situation}

Because ESP is to enable students to use English in real work, which requires teachers have knowledge and ability to bring students into learning situation, so that students can gradually construct their own knowledge framework in learning situation. For example, in order to practice spoken English, the teacher can make students in the classroom simulate an interview, negotiation, tour guide and so on and, for terms, physical scaffolding can be used to provide a vivid situation. Teachers can also stimulate students' learning motivation, so that students with low English competency can build up confidence and thus, teachers affect the role of scaffolding indirectly.

A good classroom situation should meet several basic standards: first, students can benefit from it; second, students' learning motivation can be stimulated; three, students can get knowledge by their own efforts or with others' help. This situation is the most appropriate ZDP, which the premise and guarantee of scaffolding instruction.

\subsection{Independent Exploration}

Usually, after teachers built the scaffolding and brought students into the situation, they should take the students as the center, so that students can find and understand the knowledge to learn rather than get the answer directly. In the ESP class, the teacher should point out the direction to learn for students. For example, to computer professional vocabulary, teachers can use pictures or other scaffolding for students to provide clues, so that even in the passage, or dialogue, the students can predict what to learn. It is worth mentioning that, at this stage, teachers should increase difficulty in the indirect, vague way so that the students make progress. For example, why do you translate this sentence in this way? Did you hear the message in the speech? etc.. In such way, students can gradually solve problems themselves and thus construct their own learning framework and remove scaffolding.

\subsection{Cooperative Learning}

Cooperative learning is an important part in ESP class, because the knowledge learned in the classroom will eventually be applied in the real environment, such as, how to use the knowledge of legal English to deal with foreign affairs, how to use the knowledge of medical English to participate in international aid organizations, and so on. Cooperative learning not only enables students to use the knowledge flexibly, but also can train the students' teamwork and cooperation spirits, which is very important to their future. In this process, teachers should think about the way and form to divide the students into groups, which will have direct effects on cooperative learning, and even the whole study.

\subsection{Evaluation}

Scaffolding instruction is a diagnostic and reflective teaching mode, and therefore, the evaluation is also a part of the whole teaching process. Its evaluation system not only includes the former formative assessment and the final evaluation, but also includes the evaluation of the students' group, the evaluation of the team members and the students' self-evaluation. The content of evaluation includes the ability of learning autonomy, the contribution to group learning, and the construction of knowledge. This evaluation system can be used in the teaching ESP to reduce the students' learning pressure and burden, so that they are willing to accept the results of the assessment, which can truly reflect teaching and learning effects, and promote comprehensive development of students.

\section{Conclusion}

With the globalization, the knowledge of ESP becomes necessary ability for inter-disciplinary talents. The scaffolding instruction takes students as the center, emphasizes the students' knowledge construction in learning process, and finds the best combining point in teaching and learning. It is undoubtedly a constructive attempt to apply scaffolding instruction to ESP course. However, there are some limitations in scaffolding instruction, for example, how to ensure the systematicness of knowledge, how to determine the ZDP, which is worth further exploration. 


\section{References}

[1] D.F.Shu, Foreign Language Teaching Reform: Problems and Strategies, Shanghai Foreign Language Education Press, China (2004), p.103.

[2] M.A.K.Halliday, A.Mclntosh, P.Strevens, The Linguistic Sciences and Language Teaching, The English Language Book Society and Longman Group Ltd, Britain, (1964), p.51.

[3] P.Strevens, ESP after Twenty Years: a Re-appraisal, [A], in: Tickoo M (Ed.), ESP:State of the Art[C], Seameo Regional Language Centre, Singapore,1988, p.1-13.

[4] Y.K.Ma,H.S.Ye, Psychological Development and Education, J. (2004) No.2, p.89-92.

[5] Information on http://baike.baidu .com /link?url =4R_dpY-qbkbAph7h4zg0o_m NPU7D QLoEVp GRB29mldz9Z5GljSmMY4fMiwDGgLTuIhTA5KKXQE5oWWNBfLbS7_ 